\title{
Global economic crime - acting resolutely, thinking laterally
}

\author{
by the Hon Justice Michael Kirby ACCMG
}

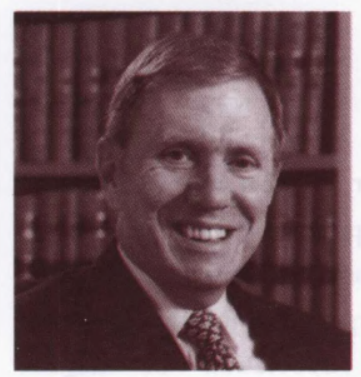

Hon Justice Michael Kirby
This article is adapted from speech presented at the 18th Cambridge International Symposium on Economic Crime, held at Jesus College, Cambridge from 10-17 September 2000.
$\Lambda$ $\mathrm{t}$ an international meeting addressing the global problems of economic crime, money laundering and transnational fraud, it would be easy to lose hope. It is hard enough to ensure effective law enforcement in domestic jurisdictions. It seems almost impossible to expect law enforcement agencies and state machinery to succeed when the challenge comes from outside the country. Lawyers usually think in jurisdictional terms. Law enforcement officers do much the same. Easier by far to tackle the manageable problems that are local than to confront the elusive criminal who manipulates cyberspace or who pulls levers from an ever shifting overseas base.

Yet the lessons of contemporary society are that antisocial individuals have perceived the potential of new technology to enhance their power and wealth. They have also understood that, in modern circumstances, they may have greater chances of wealth, and smaller chances of detection and apprehension, if they operate across state boundaries. Mules may do the local dirty work. The planners and the beneficiaries may live in comfort and safety far away. Their profits, from illegal arms sales, drug deals, financial swindles and money laundering for others demand resolute action. Yet the blinkers of jurisdiction and the incapacities of local institutions may often make effective action difficult to achieve.

I will recount three stories, derived from-my own life. They illustrate the lesson that, in confronting the problem of global criminality, we must keep in mind the need to think in institutional terms. The first story arises from the responsibilities I held between 1993 and 1996 in
Cambodia. In those years, I served as Special Representative for the Secretary-General of the United Nations for Human Rights in that country.

\section{CAMBODIA}

Before the Paris Peace Accords of 1991, Cambodia had suffered, on a per capita basis, probably more than any other country. More than 10 per cent of its population of 10 million had been killed in the 25 years of suffering that preceded the intervention of the United Nations. Years of revolution, war, genocide and invasion had meant enormous suffering. The deprivations of fundamental human rights were unimaginable. As part of the international settlement that restored Cambodia to normal life, an office was created in the United Nations to provide guidance and support in the re-establishment of constitutionalism, the rule of law, and basic rights. I was the first holder of that office.

On my initial visit to Phnom Penh I found that there were virtually no judges. There were no courtrooms, no officials and no laws. When we consider the challenge of international law and order, it is vital to remember that, in many countries, even the most rudimentary of governmental institutions may be missing. Any judge of the old regime in Cambodia who did not flee the country was almost certainly murdered by the Khmer Rouge. Accordingly, Cambodia had to start again. I remember vividly speaking to the new 'judges' in what had been the old courthouse in Phnom Penh. None of them was a lawyer. Most of them were teachers. At least they could read and write. They asked me rudimentary questions about what it meant to be a judge. 
Could they remain members of a political party? Could they accept presents? What would they do if there was no law on the subject? My task, with judges from India, Zimbabwe, France and elsewhere, was to offer a crash course in the judicial function. Similar courses have been given under the auspices of the United Nations before and since. Most recently, in East Timor, judges from many lands are working with locals to rebuild a rudimentary system for the administration of justice.

These are the truths of many countries. I explained to the 'judges' in training that it was unacceptable for them to receive gifts. If a gift were accepted from a large multinational corporation, happy with the outcome of a case, it would soon become known. No one would trust the decision of that judge. Yet I was told that it was a strong tradition in Khmer culture to offer gifts of friendship and gratitude in certain situations. I warned that this was intolerable in judicial office. The eyes of my listeners were downcast. Later it was explained to me that judges in Cambodia received as salary US\$20 a month. The only way they could survive would be by occasional gifts. Only in that way could they educate their children. I saw a look of anguish in the eyes of the new 'judges'. I could perceive their dilemma. The notions of 'privatisation' had combined with cultural politeness to suggest the supplementation of meagre public salaries. Police and guards on roadways in Cambodia regularly levied 'tolls'. It was a kind of users' contribution to the pockets of the lonely guards performing a sometimes dangerous job. Yet judges are supposed to be in a different class, I insisted. The eyes were lowered further. I was demanding a rule that was almost impossible to live by.

There can be no global rule of law without an uncorrupted judiciary. Nations can enact laws. They can subscribe to solemn international declarations. They can ratify treaties. But unless those who enforce the law are uncorrupted, it will mean little or nothing. Reliance on the uncorrupted decision-maker is something we take for granted in developed countries. But in most countries of the world the judges and magistrates are underpaid, if they have been paid at all.

\section{WORLD BANK}

My endeavours to persuade the World Bank to interest itself in the underpinnings of governance in Cambodia fell on deaf ears. This was before the new head of the Bank, Mr James Wolfensohn, an Australian, took it, with other global institutions, down the path of strengthening governmental infrastructure. Without an infrastructure of integrity, talk of money laundering laws and extradition or of drug law enforcement and international police cooperation, is rather empty. In many countries of the world the absolute prerequisite to a just, efficient and lawful implementation of high standards against international economic crime is simply not present. This is why the new interest in governance of the World Bank, the International Monetary Fund, the World Trade Organisation, the OECD, the Commonwealth of Nations and other bodies is to be applauded. Without independent and impartial courts, the building of a global rule of law will enjoy only selective success.

What is at stake in governance is not simply the enforcement by courts of contracts and commercial dealings between parties participating in the global economy. It is also essential that domestic courts should implement, honestly and effectively, international regimes that are adopted to tackle the problems of global crime. Those who want to tackle those problems effectively must give effective support to the international agencies that are helping to build or rebuild judicial institutions of integrity in countries which have never known, or have forgotten, how important such institutions are.

\section{ANTI-CORRUPTION}

The United Nations itself is now beginning to tackle the complex issues that are involved in official corruption. At the Vienna office of the UN, and under the aegis of the Office for Drug Control and Crime Prevention, a 'Global Programme Against Corruption' has been instituted. This Programme has established a number of projects concerned with the issues that involve corruption in all countries, but especially in developing countries that are most vulnerable to predatory corrupters. Some of the issues being tackled include:

- prevention and control of laundering of corrupt proceeds;

- protection of whistleblowers;

- international oversight of public procurement contracts;

- the role of civil service managers in preventing corruption;

- economic sanctions against enterprises involved in corruption;

- initiatives by parliaments against corruption; and

- corruption assessments of individual countries.

One group established within this Programme is a judicial group on strengthening integrity. That group met for the first time in Vienna in April 2000. It was chaired by Judge Christopher Weeramantry, lately Vice-President of the World Court. Its members include four Chief Justices from common law countries in Asia and four from such countries in Africa. I was elected rapporteur.

The object of the judicial group is to examine, at an international level, the causes, course and prevention of corruption in the judiciary. The participants agreed to address the systemic causes of corruption in judicial office. Their concerns ranged from judicial remuneration, appointments, codes of conduct, assignment of judges to cases, case loads and the formulation of a code of conduct 
to be observed by the judiciary. Various strategies to reduce corruption were examined including:

- the computerisation of court records;

- the provision of direct access of litigants to a judge in case of complaint;

- a requirement for judges to declare their assets publicly;

- strengthening of the law on judicial disqualification and bias;

- involvement of the media in supporting judicial integrity; and

- strengthening of the office of the public prosecutor.

\section{TRANSPARENCY INTERNATIONAL}

The United Nations group is supported by an important international NGO, Transparency International, based in Berlin and London. This is a body which monitors country reports on corruption. It ranks countries on a corruption scale. Fortunately, Transparency International, like the United Nations, realises that the problem of corruption is complex. It will not be solved by simply locking up a few officials who are caught. A culture of integrity has to be built. Levels of corruption are dependent upon such considerations as official salaries, judicial efficiency, facilities for law reform and legal development and the attitude to integrity in society as a whole. Unless the law and its institutions are efficient, there is an inevitable tendency for the rich, powerful and influential to try to cut corners and to provide rewards to those who will deliver desired outcomes.

Fortunately, a number of international agencies have recently come to understand the significance of strengthening the measures that diminish official corruption. In February 1999, the Convention on Combating Bribery of Foreign Public Officials in International Business Transactions of the OECD came into force. It is supplemented by laws of member countries designed to give effect to this Convention. Such laws provide for the punishment of public and private officials who offer corrupt inducements to foreigners. By punishing the wellfunded corrupters, and not just the vulnerable corrupted, it is hoped to put in place the mechanisms to uphold integrity. Yet such measures will be of limited value only unless the endemic causes of corruption in home institutions are effectively tackled.

Naturally, the senior judges of so many common law countries share a common heritage and a culture of integrity. When, as is hoped, they have prepared recommendations for international strategies and perhaps a global code of judicial conduct, it is anticipated that similar committees will be established for other judicial traditions. These would include the judges of Central and Eastern Europe and the former Soviet States. Another group would involve the judges of Latin America. The object is, in this way, to develop codes applicable to judges throughout the world. The purpose is to identify the causes that undermine judicial integrity. Only when this is done can a concerted effort be made to attack those causes and to solve them at their source.

Article 14 of the International Covenant on Civil and Political Rights promises that the judiciary of every land will act fairly and in public and will be 'competent, independent and impartial'. Without these qualities, strategies to tackle the problems of international economic crime will, all too often, run into insuperable obstacles. The international treaties and promises will be mere words. The best efforts of honest law enforcement will come to grief in dishonest courts.

\section{REMAINING CRITICAL}

A significant part of the problem of international economic crime is connected with the international drug trade. Narcotic and hallucinogenic drugs feed a huge market in virtually every country. The very size of that market indicates the penetration of such drugs into the lives of millions of apparently law-abiding citizens. The stereotype of the drug user and the drug dealer are often far from the truth. Most drug users in most countries are ordinary individuals who use drugs, as others do alcohol, for recreational use or out of habit or dependence.

The strategy which the international community has adopted to combat the spread of such drug use is largely, but not wholly, directed to attacking the sources of supply. In fact, it is based, substantially, in a prohibitionist model. That model, adopted originally to combat the misuse of alcohol, gathered support in the US after prohibition was first adopted in the state of Maine in the 1830s. Following the sacrifices of the Civil War, there was a great outbreak of demands for moral renewal in the US. Eventually, this led to the adoption of national Prohibition. It was a brave social experiment. Like its contemporary counterpart, communism, it was doomed to fail. We still carry the legacy of the prohibitionist movement of those days in the international response to drugs of dependence and addiction adopted at the same time. Instead of treating the problem as a medical one, the nations of the world are, for the most part, locked into a law and order enforcement approach. Its success is, and can be, only partial. In recent years, in Scandinavia, the Netherlands, Switzerland and Australia, sober voices are demanding a consideration of an alternative approach of harm minimisation and a more sophisticated mixture of legal responses than we have at present.

In voicing these opinions, I do so from the perspective of having participated for many years as a judge in Courts of Criminal Appeal, confirming convictions and imposing sentences required by Australian legislatures, themselves conforming to international treaty obligations assumed by Australia. It is not the privilege of a judge to ignore, or frustrate, the law as made by an elected Parliament. If a 
judge cannot implement the law, he or she should look for a different job or seek assignment to cases presenting no challenge to conscience. In my case, I spared the prisoners the judicial homilies. But I applied the law. Yet doing so concentrates the mind on the wisdom and efficacy of what one is doing.

My own life has made me cautious about the law's overreach. Not all laws are good or just laws. Some are misguided. Some may even be evil. I discovered this when, growing up in Australia in the 1950s and 1960s, I was confronted by laws, inherited from England, which effectively punished and stigmatised people because their sexual orientation was not that of the majority. Such laws were not always enforced. But they remained on the statute books. They gave rise to an ambivalent culture of random application and intermittent punishment. They worked a great deal of injustice and pain. I know this because I was one of the homosexual minority at whom these laws were targeted. Gradually in Australia, England and many other countries of the Commonwealth, the cloud lifted. After the Wolfenden Report of 1957, many criminal laws were reformed. One by one, the old criminal sanctions on homosexuals were repealed. But the legacy remains - with numerous civil disadvantages still suffered, to say nothing of the personal shame inflicted by social attitudes that the misguided laws reinforced.

Because of my own sexuality, these were not theoretical questions for me. They were live issues for the mind and heart. They taught me to adopt a questioning approach to the law and to try to see its inefficiencies and injustices from the viewpoint of those sometimes on the receiving end. All of us who are involved in the law should retain a healthy scepticism. We should maintain a willingness, at all times, to question received wisdom and to scrutinise and criticise the laws we help to enforce. Doing so does not relieve us of our legal duties. But nor are we exempt from questioning, for that is the responsibility of a moral person. We should never forget that the judges of Germany only once questioned a law introduced by the Nazis. It was not the Nuremberg Laws that robbed Jewish citizens of basic civil rights. It was a law concerning judicial pension entitlements. Mindless application of the law is a feature of authoritarian societies. It is not a feature to emulate.

I suspect that, in the next decade or so, there will be a complete reconsideration of our approach to drug control. No one thinks that drug addiction and dependence are good for society or for individuals. But there may be more effective ways to combat the problem. Those who are closely involved in the present laws, and know their weaknesses, should be contributing to the debates about their improvement and reform. Because a not inconsiderable part of the problem of international money laundering is a consequence of the global drug trade, it is essential to examine such questions. The answer to the problem of global crime will not be found only in an increase of official powers, the enlargement of offences and the building of more prisons. Sometimes we must think laterally, even if this involves questioning fundamentals.

Each of the topics I have explored illustrates the growing influence of international law and its institutions. In the world of the global economy, global crime is inevitable. We must be vigilant to meet its challenges. But those challenges will not be answered by treaties alone or and by co-operation amongst law enforcement agencies. Reinforcing good governance is essential. Strengthening the independent judiciary is necessary. And constantly reexamining the laws that we enforce is our obligation.

The Honourable Justice Michael Kirby AC CMG

Justice of the High Court of Australia

Justice Michael Kirby has been a Justice of the High Court since 1996, and is one of Australia's longest serving judges, having served in the Australian Conciliation and Arbitration Commission, the Australian Law Reform Commission and in 1983 been appointed as a Judge of the Federal Court of Australia. In 1984 he became President of the New South Wales Court of Appeal and in 1995 was appointed President of the Court of Appeal of Solomon Islands. These posts were relinquished on his elevation to the High Court. Justice Kirby holds numerous positions in international agencies and several Honorary Doctorates. He was awarded the Australian Human Rights Medal in 1991 and the UNESCO Prize for Human Rights Education in 1998. He is a Companion of the Order of St Michael and St George (CMG) and a Companion of the Order of Australia. 